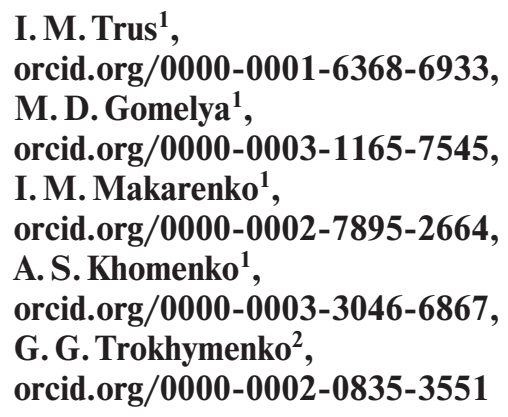

1 - National Technical University of Ukraine "Igor Sikorsky Kyiv Polytechnic Institute", Kyiv, Ukraine, e-mail: inna. trus.m@gmail.com

2 - Admiral Makarov National University of Shipbuilding, Mykolaiv, Ukraine

\title{
THE STUDY OF THE PARTICULAR ASPECTS OF WATER PURIFICATION FROM THE HEAVY METAL IONS USING THE METHOD OF NANOFILTRATION
}

Purpose. To develop highly efficient technologies for deep purification of natural water and wastewater from heavy metal compounds and ions using nanofiltration membranes and complexes to prevent water pollution and protect people and natural objects from the effects of highly toxic pollutants.

Methodology. To remove copper ions from the investigated solutions, potassium ferrocyanide was used as a precipitant; the cationic flocculant Zetag-7547 was used to improve the sedimentation properties of the obtained solid phase. To extract copper, zinc, cadmium, and nickel ions, HEDP and NTMP complexes were used at a concentration of $10-50 \mathrm{mg} / \mathrm{dm}^{3}$. After adding the reagents, the solutions were desalted on a low pressure nanofiltration membrane OPMN-P.

Findings. The optimal conditions for water purification from copper ions by complexation-nanofiltration method were determined. A method for efficient extraction of heavy metals from water to acceptable limits using complexones with subsequent nanofiltration desalination was developed.

Originality. As a result of the conducted research, dependence of productivity of nanofiltration membrane OPMN-P on the pressure, selectivity to ions of copper, zinc, cadmium, nickel and on the degree of selection of permiatewas was established. The dependence of the efficiency of pollutant extraction on the type and consumption of complexoneswas was established. It is shown that the hardness ions, hydrocarbons, chlorides, sulfates reduce the selectivity of the nanofiltration membrane to heavy metal ions, so it is proposed to increase the efficiency of the process to pre-purify water on the anionite AV-17-8 in the basic form. Potassium ferrocyanide was used as a precipitant to remove copper ions from the test solutions, and a solution of the cationic flocculant Zetag-7547 was used to improve the sedimentation properties of the obtained solid phase, followed by purification on a nanofiltration membrane, which allowed increasing the degree of extraction of $\mathrm{Cu}^{2+}$ ions to $99.6 \%$.

Practical value. The optimal technological parameters of heavy metal ions extraction from aqueous solutions by means of nanofiltration methods using complexons are substantiated in the work. The developed methods for the extraction of heavy metal ions from aqueous solutions allow reducing their concentrations to normative values. Integrated technologies for water purification from heavy metals make it possible to reduce the man-caused impact on the environment by improving water quality and reducing the amount of waste generated, and to improve the environmental situation in the region.

Keywords: wastewater, pollutants, heavy metals, hardness ions, nanofiltration, complexone, selectivity

Introduction. The beginning of the $21^{\text {st }}$ century is characterized by a large number of scientific and technical achievements, as well as the deterioration of the environment due to its pollution. Despite the decrease in industrial production, there is an increase in pollution of the surface and ground waters. Therefore, today the problem of protection of the hydroecosystems from pollution by various pollutants is quite acute.

The quality of water sources is determined by their chemical composition, which is an integral indicator of the natural and anthropogenic factors. Nowadays, the intensive development of technology leads to the formation of large amounts of waste. The situation is complicated by the lack of cost-effective technological solutions for the processing of this waste. Increasing anthropogenic pressure on the environment leads to significant depletion and pollution of water resources [1,2]. Surface waters, which are sources of water supply for the population and industrial enterprises, are most affected. Thus, clean fresh water is one of the most important scarce natural resources. In addition, the water demand for industrial, communal and agricultural needs is constantly growing. It is clear that high pollution of water bodies with pollutants requires immediate measures to reduce environmental risk, as the planet's water resources can be in a catastrophic state [3, 4].

(C) Trus I. M., Gomelya M.D., Makarenko I. M., Khomenko A.S., Trokhymenko G. G., 2020
Today, the spread of pollutants in water bodies reaches a global scale. The content of man-made toxicants, including heavy metals, often exceeds the established standards. Heavy metals are released into the environment due to natural processes and anthropogenic influences. Natural sources include forest fires, dispersion of the dust containing heavy metals by wind. The processes of urbanization and industrialization have a much greater negative impact. Enterprises of mechanical engineering (galvanic baths of copper, nickel plating, cadmium plating, chrome plating), ferrous and non-ferrous metallurgy, chemical production dump untreated or insufficiently treated effluents that enter rivers, lakes and other surface water bodies [5]. Nuclear power plants have a significant impact on the content of heavy metals in reservoirs. Galvanic production is characterized by significant consumption of fairly high quality water and discharge of large amounts of hazardous wastewater, so it is one of the largest polluters of water sources with heavy metals, which have carcinogenic, mutagenic properties and cumulative effect [6]. The content of heavy metal ions in water is quite high; moreover, they are very toxic to humans. The negative impact of heavy metals on the reservoir is determined not only by the concentration of pollutant, but also depends on the form of the existence of heavy metals. Dissolved forms of metals have a greater negative effect, the toxic effect will be less if the metals become part of mineral or organic compounds or exist in colloidal disperse form. In the following sequence, the toxicity decreases: 
Hydrated metal ions $(\mathrm{M})^{n+}$; simple complexes with inorganic anions $\mathrm{MCl}_{m}{ }^{n-m},\left(\mathrm{MHCO}_{3}\right)^{n-2} \rightarrow$ Metal complexes with humic or fulvic acids; complexes with sulfur-containing MSR ligands and amino acids $\mathrm{M}\left(\mathrm{NH}_{2}-\mathrm{CH}_{2}-\ldots-\mathrm{CH}_{2} \mathrm{OOH}\right) \rightarrow$ Metals adsorbed on the surface of suspended particles: $\mathrm{Mn}^{+}-\mathrm{Fe}_{2} \mathrm{O}_{3} \times$ $\times n \mathrm{H}_{2} \mathrm{O}$. However, due to the low concentration of heavy metals in reservoirs, a wide range of $\mathrm{pH}$ values, the presence of various high molecular weight organic compounds in natural waters, it is difficult to determine the state and shape of heavy metal ions.

Copper is an important component of the body. Bioavailability and toxicity depend on the forms of existence in water. The forms of $\mathrm{Cu}^{2+}$ compounds in aquatic ecosystems depend on the processes of hydrolysis, complexation and $\mathrm{pH}$ of the medium. Basically, copper in surface waters is in a dissolved state. Its carcinogenic or mutagenic properties have not been established. The maximum permissible concentration (MPC) for surface water sources used for drinking purposes is $1 \mathrm{mg} / \mathrm{dm}^{3}$, for fishery reservoirs $-0.001 \mathrm{mg} / \mathrm{dm}^{3}$.

Cadmium is a very highly toxic metal. The ways it enters the hydrosphere are: leaching from soils and rocks, removal of effluents from the beneficiation and mining industries, precipitation and surface runoff of agricultural lands. Secondary pollution is possible when there is a mass extinction of aquatic organisms, which contain significant amounts of cadmium in their bodies. In addition, when entering the reservoir, cadmium slows down the self-cleaning process. The maximum concentration limit of cadmium for surface waters used for drinking purposes is $1 \mu \mathrm{g} / \mathrm{dm}^{3}$, in fishery reservoirs $-0.0005 \mathrm{mg} / \mathrm{dm}^{3}$. The permissible concentration in fish products is $0.1 \mathrm{mg} / \mathrm{kg}$ of raw weight. The threshold of toxic action of this pollutant on hydro bionts is $0.15 \mu \mathrm{g} / \mathrm{dm}^{3}$.

Zinc is one of the important trace elements needed by humans. But at high concentrations it leads to the negative consequences - skin irritation, stomach cramps, anemia and nausea. It enters the reservoirs during the discharge of wastewater from metallurgical and beneficiation plants, galvanic enterprises, enterprises for the production of fiber and paints. Upon entering the reservoir, zinc leads to the inhibition of phytoplankton photosynthesis. The maximum permissible concentration of zinc in the surface water used for drinking purposes is $1000 \mu \mathrm{g} / \mathrm{dm}^{3}$, for fishery reservoirs $-0.01 \mathrm{mg} / \mathrm{dm}^{3}$.

Nickel is carcinogenic to humans, in excess of acceptable concentrations leads to kidney and lung diseases. The maximum concentration limit of nickel for surface water bodies used for drinking purposes is $20 \mu \mathrm{g} / \mathrm{dm}^{3}$, for fishery reservoirs $-10 \mathrm{mg} / \mathrm{dm}^{3}$.

Rational use of water resources, improvement of water quality, preservation of the volume necessary for self-purification is important for ensuring the high quality of water resources.

Therefore, to reduce the harmful effects, it is necessary to develop highly efficient methods for water purification from various pollutants, which will return water to the production cycle in order to reduce the consumption of clean fresh water from surface and groundwater.

Therefore, the problem of developing efficient, low-waste technologies for the removal of heavy metal ions from natural and wastewater is extremely relevant. This will reduce the level of pollution of water bodies and improve the ecological situation of the regions.

Literature review. Today, the requirements for environmental protection from various pollutants, including heavy metals, are toughened. Heavy metals have high toxicity at relatively low doses; furthermore, they have the ability to accumulate in living organisms. This necessitates the environmental control over the content of heavy metals in drinking water, as declared by national regulations and documents of the World Health Organization.

Protection of the aquatic ecosystems from various pollutants during the discharge of industrial wastewater is possible only with the introduction of the reversible water supply cycles. But for the introduction of circulating water supply in enterprises, it is necessary to develop ways of deep water purification from the various pollutants.
The choice of the method for water purification from pollutants depends on the type and concentration of the pollutant, the conditions of use of the method to bring the concentration of the substance to the normative values, which will create reliable ways to protect groundwater and surface water. When choosing a method, one should pay attention to the sensitivity, reproducibility and accuracy of the analysis. Various methods are used to extract heavy metals, both directly and with different sequence combinations. The most widely used methods are: mechanical/physical (settling, filtration), chemical (reagent treatment) [8, 9], membrane (ultrafiltration, nanofiltration, reverse osmosis, electrodialysis) $[10,11]$, electrochemical (electrocoagulation, electrolysis, electroflotation, electrodialysis) [12-14], biological [15, 16], sorption (ion exchange, sorption filters) $[17,18]$, coagulation-flotation (flotation, coagulation, flocculation) [19] methods, and others.

Sorption purification methods are among the most environmentally friendly methods, and they are also characterized by high process efficiency. When using the adsorption method, it is possible to reduce the concentrations of heavy metals to fairly low concentrations, but its main disadvantage is the very high cost of sorbents. Therefore, sorption methods will be cost-effective only with the repeated use of sorbents. But during the regeneration of sorbents, highly toxic and highly concentrated solutions are formed, which need to be further neutralized. Also, for the widespread introduction of these technologies, it is necessary to address the issues of low sorption capacity of materials, low selectivity of sorbents and development of methods for disposal of heavy metals from waste.

The use of ion exchange processes has its limitations: the ion exchange units are supplied with water that has been previously purified from suspended solids, petroleum products, iron ions, and so on. This hinders their widespread adoption to create environmentally friendly technologies.

Electrocoagulation, electroflotation and electrodialysis are advanced and effective technologies for extracting heavy metals from aqueous solutions. When using electrochemical methods from aqueous solutions, it is possible to remove valuable components without the use of chemical reagents in a fairly simple and automated process. But the main disadvantage of these methods is the high cost of electricity.

The use of biological methods is cost-effective and does not lead to the secondary water pollution. But the scope of this method is limited by the duration of adaptation of microorganisms; in addition, some difficulties may occur in case of violating the technological regime of purification.

The main advantages of flotation in the wastewater treatment from heavy metals are high efficiency and productivity of the process. Practical application is limited by insufficient study on the process of selection of reagents, which will increase the efficiency, selectivity and reduce the loss of flotation reagent.

The analysis of literature data showed that reagent methods are widely used for wastewater treatment in galvanic industries. They are quite cheap and easy to implement, so the development of this direction of cleaning remains quite promising [20]. The following reagents are mainly used to extract heavy metals from water: lime, sodium bisulfite, and iron sulfate. Disadvantages of reagent deposition include: insufficient efficiency of water purification, the need to use a large number of reagents and the formation of significant amounts of toxic sludge. In addition, when using reagents for the extraction of heavy metals there is an increase in the salt content of purified water, which makes it impossible to use in circulating water supply systems of enterprises.

One of the modern ways to solve the problem of extraction of heavy metals from aqueous solutions is the use of membrane methods. The advantages of baromembrane methods are that they are easy in operation, have small dimensions of construction units, have low energy consumption, as energy is spent only on creating high pressure, provide the ability to obtain high quality water. Reverse osmosis allows achieving a fairly high efficiency of water purification from heavy metals, 
but its main disadvantage is the high cost of the process and the need for preliminary preparation of solutions.

In addition, when using these methods separately it is impossible to achieve modern requirements for the extraction of heavy metals: reducing the concentration of heavy metals to MPC, low cost of purification, disposal and return of valuable components, return of water for recycling to reduce fresh water intake and reduce discharges. Therefore, it is necessary to develop comprehensive technologies that will optimize water consumption of industries.

It is economically feasible and environmentally safe to develop technologies for nanofiltration purification of water from heavy metals using complexes to increase the efficiency of the process. This will minimize the impact of waste and industrial waters containing heavy metals on the environment.

Purpose. The aim of this work is to develop a highly efficient low-waste technology for deep wastewater treatment from heavy metals on the nanofiltration membrane of low pressure OPMN-P using complexes to ensure environmental safety.

To successfully solve the problem of water purification from heavy metal ions, the following tasks were set:

- determination of the effect of potassium ferrocyanide and cationic flocculant Zetag-7547 on the efficiency of nanofiltration extraction of copper ions;

- determination of the selectivity and productivity of nanofiltration membrane OPMN-P with the help of ions of copper, cadmium, zinc, nickel depending on pressure and degree of selection of permiate;

- assessment of the prospects for the use of complexes in nanofiltration for efficient extraction of heavy metal ions;

- study on the effect of hardness ions on the efficiency of water purification from heavy metals using the membrane OPMN-P.

Results. For the research, working solutions were prepared on Kyiv tap water $\left(C\left(\mathrm{Na}^{+}\right)=19.8 \mathrm{mg} / \mathrm{dm}^{3} ; C\left(\mathrm{~K}^{+}\right)=4.4 \mathrm{mg} / \mathrm{dm}^{3}\right.$; $\left.C\left(\mathrm{Ca}^{2+}\right)=68.1 \mathrm{mg} / \mathrm{dm}^{3} ; C\left(\mathrm{Mg}^{2+}\right)=11.2 \mathrm{mg} / \mathrm{dm}^{3}\right)$ and distilled water with concentrations of heavy metals $\left(C\left(\mathrm{Cu}^{2+}\right)=5 \mathrm{mg} / \mathrm{dm}^{3}\right.$; $\left(C\left(\mathrm{Cd}^{2+}\right)=5 \mathrm{mg} / \mathrm{dm}^{3} ;\left(C\left(\mathrm{Zn}^{2+}\right)=5 \mathrm{mg} / \mathrm{dm}^{3} ;\left(C\left(\mathrm{Ni}^{2+}\right)=\right.\right.\right.$ $\left.=5 \mathrm{mg} / \mathrm{dm}^{3}\right)$ The concentrations of heavy metals were relatively low, as it was important to determine the conditions of their effective extraction and to determine their residual concentrations in water.

For effective nanofiltration purification from copper ions potassium ferrocyanide with a concentration of 1 to $15 \mathrm{mg} / \mathrm{dm}^{3}$ and cationic flocculant Zetag-7547 with a concentration of 5, $10 \mathrm{mg} / \mathrm{dm}^{3}$ were used.

To increase the selectivity of the membrane for copper, zinc, cadmium, and nickel ions, complexones, oxyethylidenediphosphonic acid (HEDP) and nitriltrimethylenephosphonic acid (NTMP), were added to the initial solutions. The consumption of HEDP was $10-50 \mathrm{mg} / \mathrm{dm}^{3}$ and $50 \mathrm{mg} / \mathrm{dm}^{3}$ for NTMP.

Nanofiltration membrane OPMN-P was used for purification. This membrane has the following characteristics:

maximum temperature $-45^{\circ} \mathrm{C}$;

working $\mathrm{pH}$ range $-2-12$;

working pressure $-1.6 \mathrm{MPa}$;

minimum productivity on a filtrate at a temperature of

$25{ }^{\circ} \mathrm{C}-100 \mathrm{dm}^{3} / \mathrm{m}^{2} \cdot \mathrm{h}$;

selectivity of $0.2 \% \mathrm{MgSO}_{4}^{-}$not less than $98.5 \%$;

selectivity of $0.15 \% \mathrm{NaCl}^{-}$not less than $55.0 \%$.

To evaluate the efficiency of the nanofiltration water purification with respect to the extraction of heavy metal ions using a nanofiltration membrane OPMN-P water filtration was performed under the static conditions with the stirring of the solution. The solution was poured into a cell with a volume of $1.0 \mathrm{dm}^{3}$ with a membrane area of $113.04 \mathrm{~cm}^{2}$. After that, $100 \mathrm{~cm}^{3}$ of permiate samples was taken. The working pressure was $0.15-0.40 \mathrm{MPa}$. The pressure was created by a compressor, a manometer was used for control, and a valve was used to regulate the excess pressure. The permiate content of heavy metals was determined.
To determine the concentrations of heavy metal ions in aqueous solutions, we used the equipment and method of chronopotentiometry, which allows recording the concentrations of heavy metals with an accuracy of $1 \cdot 10^{-3} \mu \mathrm{g} / \mathrm{dm}^{3}$.

The selectivity of the membrane for the components of the solution was calculated by the formula [11]

$$
R=\frac{C_{0}-C_{n}}{C_{0}} \cdot 100,
$$

where $C_{0}, C_{p}$ are concentration in the initial solution and permiate, respectively.

After the first test for each subsequent one, the increase in the concentration of copper, cadmium, zinc or nickel due to the accumulation in the concentrate was taken into account.

The performance of the nanofiltration membrane was calculated by the formula

$$
J=\frac{\Delta V}{S \cdot \Delta t},
$$

where $\Delta V$ is the volume of permiate $\left(\mathrm{dm}^{3}\right) ; S$ is the area of the membrane $\left(\mathrm{m}^{2}\right) ; \Delta t$ is the sampling time $(\mathrm{h})$.

When evaluating the efficiency of nanofiltration purification of water from heavy metals, it was found that with increasing the degree of permiate selection, the performance of the membrane OPMN-P did not change. With increasing operating pressure from 0.25 to $0.40 \mathrm{MPa}$, there is an increase in membrane productivity from 9.5 to $13.0 \mathrm{dm}^{3} / \mathrm{dm}^{2} \cdot \mathrm{h}$. Therefore, further studies were performed at a pressure of $0.40 \mathrm{MPa}$.

In the first stage of the research, potassium ferrocyanide was used as a precipitant to remove copper ions from the studied solutions, because heavy metal ferrocyanides have low solubility. The concentration of potassium ferrocyanide solution varied from 1 to $15 \mathrm{mg} / \mathrm{dm}^{3}$. The concentration of copper ions was reduced from 5.0 to $0.42 \mathrm{mg} / \mathrm{dm}^{3}$ for a solution prepared in distilled water and to $0.22 \mathrm{mg} / \mathrm{dm}^{3}$ in tap water. As can be seen from Fig. 1 with increasing concentration of potassium ferrocyanide there is a decrease in the concentration of copper ions for model solutions prepared in distilled water. The efficiency of extracting copper ions from solutions prepared in tap water is almost independent of the dose $\left[\mathrm{Fe}(\mathrm{CN})_{6}\right]^{4-}$.

To increase the efficiency of water purification from heavy metals, it is advisable to use the reagent baromembrane methods that combine the processes of nanofiltration and precipitation.

In dilute solutions, the interaction of potassium ferrocyanide with the cationic flocculant will crosslink the molecules. As a result, the solubility of the formed complexes will decrease, which will allow removing heavy metals from water in relatively low concentrations efficiently.

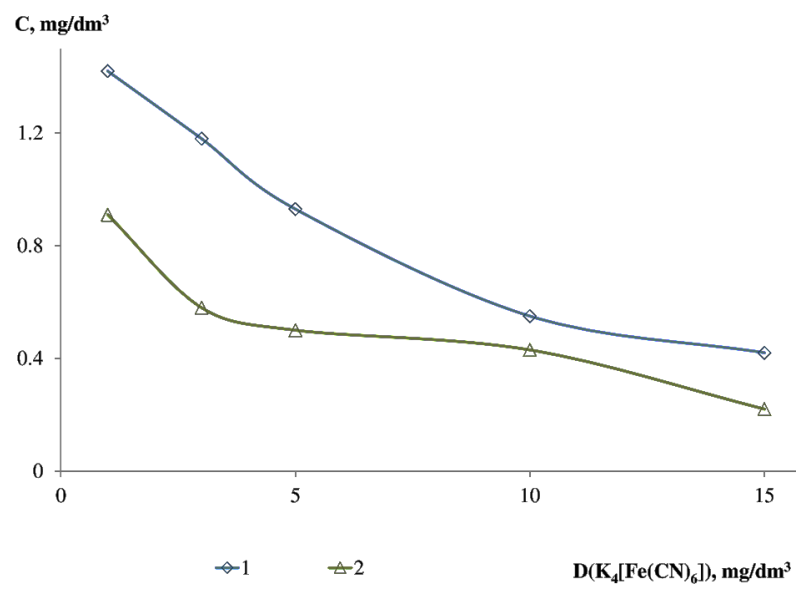

Fig. 1. The dependence of the residual concentration of copper ions on the consumption of ferrocyanide model solutions prepared in distilled (1) and tap (2) water 
Residual concentrations of copper significantly exceed the maximum concentration limits, so to improve the sedimentation properties of the obtained solid phase a solution of cationic flocculant Zetag-7547 with a concentration of 5 and $10 \mathrm{mg} / \mathrm{dm}^{3}$ was used.

At a concentration of potassium ferrocyanide of $10-15 \mathrm{mg} /$ $\mathrm{dm}^{3}$, copper ions are quite efficiently removed from the solution. Increasing the dose of potassium ferrocyanide from 1 to $15 \mathrm{mg}$ / $\mathrm{dm}^{3}$ increases the efficiency of extraction of copper ions to 99.1 and $99.6 \%$ at the consumption of Zetag-7547, which equals 5 and $10 \mathrm{mg} / \mathrm{dm}^{3}$ for distilled and tap water respectively. Residual concentrations of copper are 0.04 and $0.02 \mathrm{mg} / \mathrm{dm}^{3}$. The use of the nanofiltration method allows achieving a high degree of extraction of $\mathrm{Cu}^{2+}$ ions from solutions. It should be noted that in the purified water the residues of polycationite and ferrocyanidein a result of the analysis were not recorded (Fig. 2).

Subsequent studies on the purification of water from copper ions reviewed the effect of complexes HEDP and NTMP. The use of HEDP with a concentration of $50 \mathrm{mg} / \mathrm{dm}^{3}$ was quite effective. The selectivity of the membrane throughout the process is $100 \%$ (Fig. 3).

The use of NTMP with a concentration of $10 \mathrm{mg} / \mathrm{dm}^{3}$ was ineffective. While the degree of permiate selection was $90 \%$, the selectivity of the membrane for copper ions did not exceed $25 \%$. To increase the selectivity of the OPMN-P membrane, NTMP with a concentration of $50 \mathrm{mg} / \mathrm{dm}^{3}$ was used, which allowed purifying water from copper ions completely.

To evaluate the effect of hardness ions on the efficiency of the process in further studies solutions prepared with tap water were used. When adding NTMP complex with a concentration of $50 \mathrm{mg} / \mathrm{dm}^{3}$, the selectivity of the membrane for copper ions was $100 \%$, for hardness ions it did not exceed $4 \%$. NTMP molecules form polynuclear complexes with copper ions, because they are quite large, they are retained on the membrane, which allows removing copper ions completely. With the cations $\mathrm{Ca}^{2+}$ and $\mathrm{Mg}^{2+}$ NTMP forms stable mononuclear chelate structures that pass through the membranes of OPMN-P. This explains the low selectivity of nanofiltration purification for copper ions when using NTMP.

It is known that the chelated structures of hardness ions with NTMP are quite strong. They provide a significant reduction in the rate of crystallization of calcium carbonates or sulfates, carbonates and magnesium hydroxides, which ensures the high efficiency of these reagents in preventing the softening of aqueous solutions of calcium and magnesium salts when heated and alkalized. In this case, NTMP causes the destruction of hydrate complexes of calcium and magnesium in the aqueous medium,

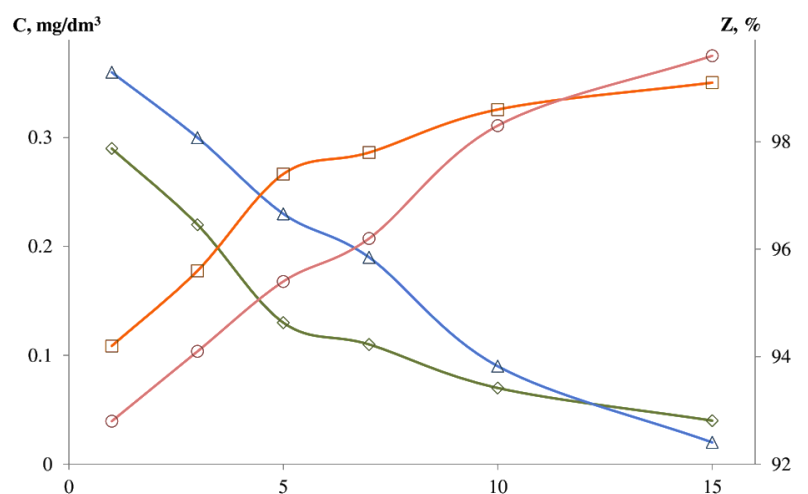

$\rightarrow 1 \quad \triangle 3 \quad \uplus_{2} \quad \ominus_{4} \quad \mathrm{D}\left(\mathrm{K}_{4}\left[\mathrm{Fe}(\mathrm{CN})_{6}\right), \mathrm{mg} / \mathrm{dm}^{3}\right.$

Fig. 2. The dependence of the residual concentration of $\mathrm{Cu}^{2+}$ ions $(1,3)$ and the degree of extraction $(2,4)$ after nanofiltration on the dose of potassium ferrocyanide at a consumption of polycationite Zetag- 7547 which was $5(1,2)$ and 10 $(3,4) \mathrm{mg} / \mathrm{dm}^{3}$ for distilled and tap water respectively

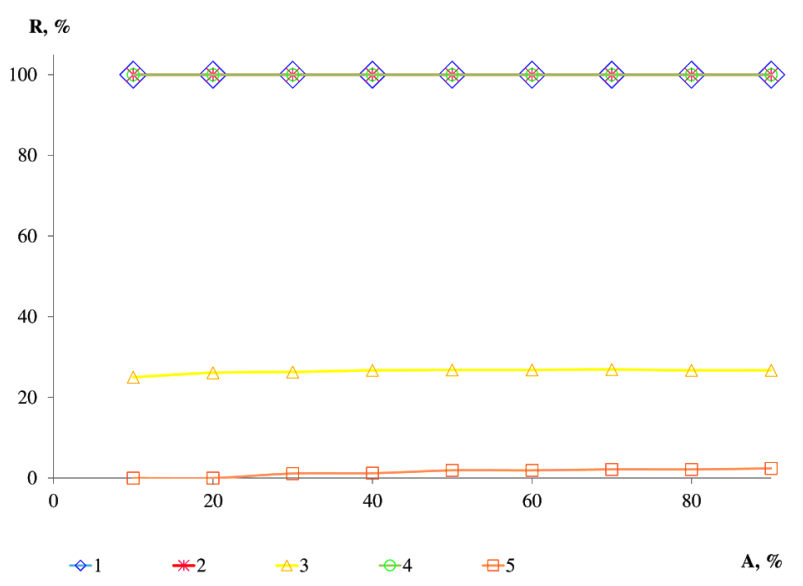

Fig. 3. Dependence of selectivity of nanofiltration membrane to copper (1-4) and hardness ions (5) on the degree of permiate selection.

Complexones: HEDP $\left(50 \mathrm{mg} / \mathrm{dm}^{3}\right)(1) ; \operatorname{NTMP}\left(50 \mathrm{mg} / \mathrm{dm}^{3}\right)(2,4$, 5), NTMP $\left(10 \mathrm{mg} / \mathrm{dm}^{3}\right)$ (3). Solutions were prepared on distilled water (1-3) and tap water (4, 5)

which significantly impairs their retention on the nanofiltration membrane. After all, hardness ions are retained much better on nanofiltration membranes in the absence of NTMP. The selectivity of the membranes in this case reaches $80 \%$.

In the case of copper ions, the complex-NTMP can interact with them both through the formation of ionic bonds and through the formation of complex bonds formed by the interaction of metal $d$-electrons with phosphorus $d$-orbitals. This promotes the formation of 2 polynuclear complexes with large dimensions, which are well-retained by the nanofiltration membrane. Polynuclear complexes are formed at significant concentrations of NTMP $\sim 50 \mu \mathrm{g} / \mathrm{dm}^{3}$. The degree of extraction of copper reaches $100 \%$. At a concentration of NTMP equal to 10 $\mathrm{mg} / \mathrm{dm}^{3}$, the selectivity of the membrane reaches only $\sim 25 \%$.

When using the complexes HEDP and NTMP for water purification from cadmium, it was found that HEDP with a concentration of $50 \mathrm{mg} / \mathrm{dm}^{3}$ allows one to completely remove this cation (Fig. 4).

The selectivity of the membrane for cadmium was quite low when used as a complex NTMP. At the degree of permiate selection of $90 \%$, this parameter did not exceed $40 \%$.

In this case, cadmium ions easily form polynuclear complexes with HEDP, the molecule of which contains four $\mathrm{P}-\mathrm{O}$ groups.<smiles>CC(O)(P(=O)([O-])[O-])P(=O)([O-])[O-]</smiles>

This promotes the formation of the ionic bonds between this molecule and two or more cadmium ions at once and promotes the formation of large polynuclear complexes. NTMP has a pyramid structure, which is not very convenient for the formation of polynuclear complexes. NTMP structure is described as follows<smiles></smiles> 


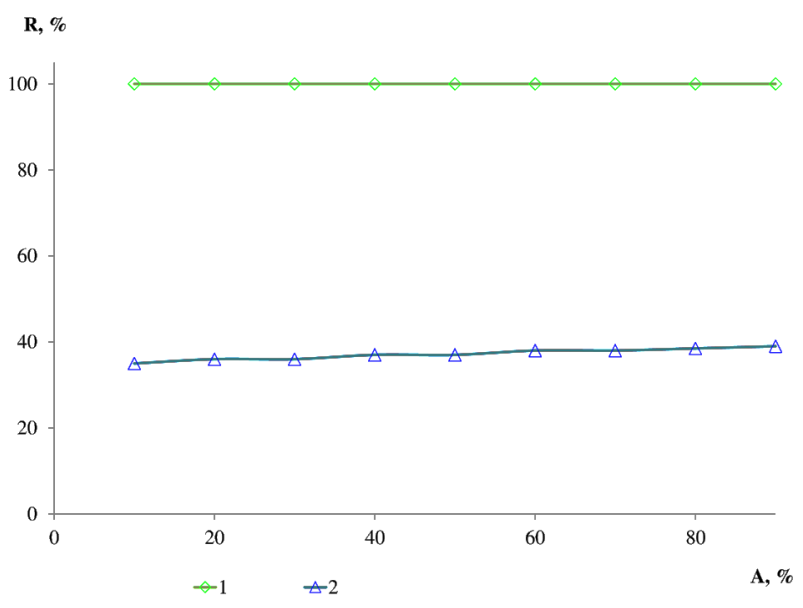

Fig. 4. The dependence of the selectivity of the nanofiltration membrane for cadmium on the degree of selection of permiate when filtering solutions of cadmium sulfate in distilled water.

Complexones: HEDP $\left(50 \mathrm{mg} / \mathrm{dm}^{3}\right)(1) ; N T M P\left(50 \mathrm{mg} / \mathrm{dm}^{3}\right)(2)$

In this case, cadmium ions, as well as hardness ions, form mononuclear complexes that are poorly retained by the nanofiltration membrane.

A similar pattern is observed during the purification of water from zinc ions. The low selectivity when using NTMP can be explained by the formation of mononuclear complexes with these cations, which are not retained by the membrane (Fig. 5). The efficiency of the process does not depend on the degree of selection of permiate. The selectivity of the nanofiltration membrane to zinc ions when used as a complex NTMP was at the level of $50 \%$, while for HEDP it was $100 \%$. The content of zinc ions in the concentrate increased in proportion to their removal from the permiate.

Due to the fact that the selectivity of the membrane using HEDP with a concentration of $50 \mathrm{mg} / \mathrm{dm}^{3}$ is $100 \%$, this complex was used to purify solutions prepared in tap water. Selectivity to cadmium ions was $83-94 \%$, to zinc reached $80 \%$, to hardness ions was at the level of $60 \%$ (Fig. 6).

The decrease in the selectivity of the extraction of cadmium and zinc ions on the nanofiltration membrane in the presence of hardness ions is due to the fact that the hardness ions from HEDP can also form polynuclear complexes. However, their binding involves a significant amount of phosphonate, which reduces the binding efficiency of cadmium or zinc ions

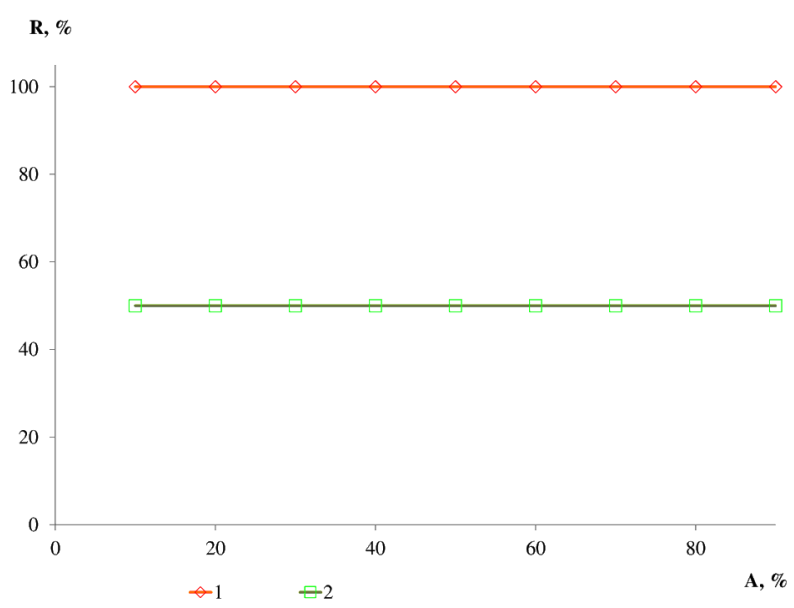

Fig. 5. The dependence of the selectivity of the nanofiltration membrane on zinc on the degree of selection of permiate when filtering solutions of zinc sulfate in distilled water. Complexones: HEDP $\left(50 \mathrm{mg} / \mathrm{dm}^{3}\right)(1) ; \operatorname{NTMP}\left(50 \mathrm{mg} / \mathrm{dm}^{3}\right)$ (2) in polynuclear complexes. This effect is quite significant, considering that $5 \mathrm{mg}$ of cadmium or zinc in water contains $\sim 80 \mathrm{mg}$ of calcium ions and $15 \mathrm{mg}$ of magnesium ions, or $0.089 \mathrm{mg}$-eq of cadmium or $0.15 \mathrm{mg}$-eq of zinc; tap water contains $\sim 4,5 \mathrm{mg}$-eq of hardness ions.

Therefore, in order to completely remove zinc and cadmium from water, it is necessary to first remove hardness ions. The process of ion exchange on the anion exchange resin in the basic form will be quite effective in this case [11].

To increase the efficiency of water purification from nickel ions, complexes of HEDP and NTMP with a concentration of $50 \mathrm{mg} / \mathrm{dm}^{3}$ were also used (Fig. 7).

When using HEDP it was found that the efficiency of water purification is quite low. The use of NTMP as a complex made it possible to completely remove nickel ions from distilled water. When purifying a solution of nickel in tap water, it was found that the selectivity of the membrane tonickel ions does not exceed $38 \%$ while to the hardness ions it was $50 \%$.

Obviously, despite the specific structure of HEDP, it forms mononuclear complexes with nickel ions, which are poorly retained on the membrane. With NTMP, nickel ions with the dorbit are able to form complex bonds with the d-orbitals of phosphorus and form larger polynuclear complexes in distilled water, so they are completely removed on the nanofiltration membrane.

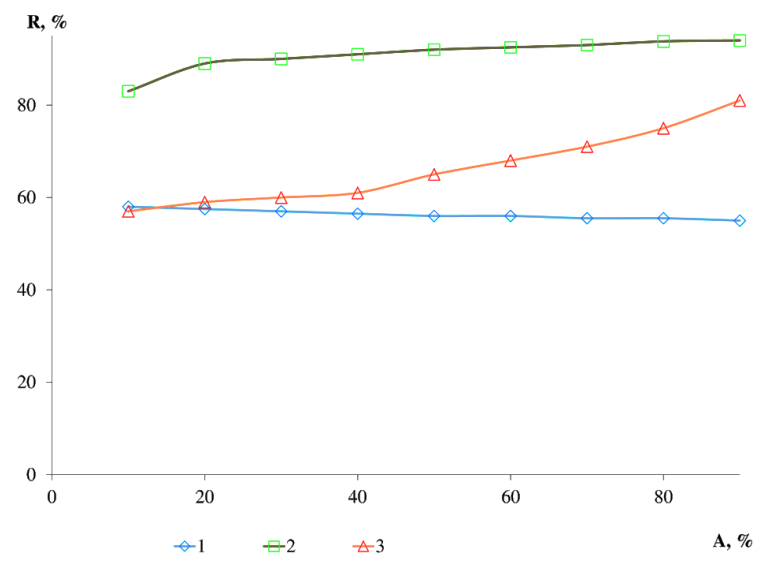

Fig. 6. The dependence of the selectivity of the nanofiltration membrane on the ions of hardness (1), cadmium (2), zinc (3) on the degree of selection of permiate when filtering solutions in tap water using the HEDP complex $\left(50 \mathrm{mg} / \mathrm{dm}^{3}\right)$

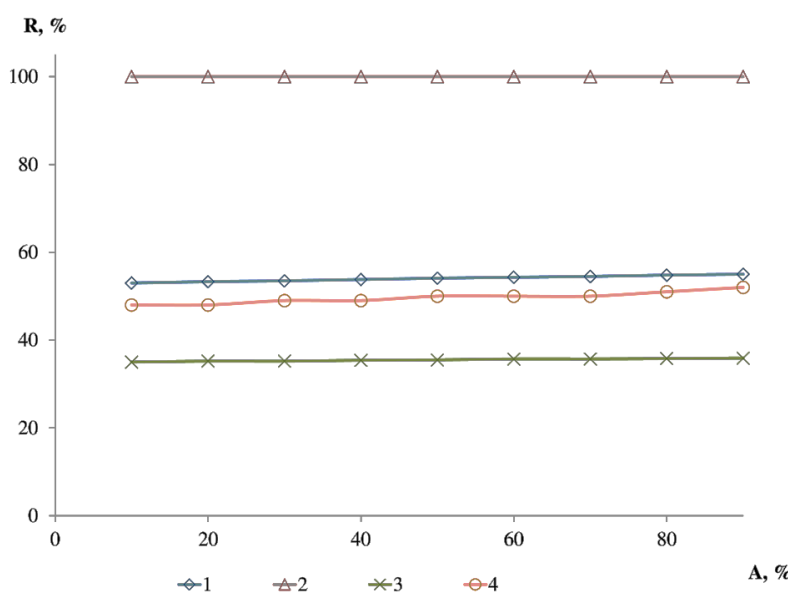

Fig. 7. The dependence of the selectivity of the nanofiltration membrane for the nickel ions (1-3) and the hardness ions (4) on the degree of selection of permeate.

Complexones: HEDP $\left(50 \mathrm{mg} / \mathrm{dm}^{3}\right)(1)$; NTMP $\left(50 \mathrm{mg} / \mathrm{dm}^{3}\right)(2-$ 4). Solutions prepared in distilled water $(1,2)$, tap water $(3,4)$ 
In tap water, where hardness ions are present in significant concentrations, they are only partially bound by complexes. It is possible that in polynuclear complexes formed with the help of nickel ions, a significant part of the sorption volume is occupied by hardness ions. This leads to a decrease in the efficiency of water purification from the nickel ions and increase the efficiency of removal of the hardness ions. In this case, it can be concluded that the hardness ions are competitive with the nickel ions.

Studies to determine the effect of temperature on the efficiency of extraction of heavy metals showed that the selectivity for these cations with increasing temperature to $30{ }^{\circ} \mathrm{C}$ remained practically unchanged.

Therefore, for deep purification of water from ions of copper, zinc, cadmium and nickel, water should be passed through the anion exchange resin, which will remove certain anions and partially soften the water [11]. Then it is advisable to use complexes HEDP and NTMP with subsequent nanofiltration purification. This will reduce the concentration of heavy metals to acceptable regulatory values.

Conclusions.

1. The paper identifies the possibility of using the method of complexation-flocculation to purify water from the copper ions. It was found that at a dose of potassium ferrocyanide at $15 \mathrm{mg} / \mathrm{dm}^{3}$ and of polycationic Zetag-7547 at $10 \mathrm{mg} / \mathrm{dm}^{3}$ the efficiency of the process is $99.6 \%$.

2. It was established that the nanofiltration membrane of low pressure OPMN-P is characterized by high productivity, which increases the degree of permiate selection from 10 to $90 \%$; the working pressure should be increased from 0.25 to $0.40 \mathrm{MPa}$ in this case.

3. The optimal technological parameters for extraction of heavy metal ions from aqueous solutions with the help of complexones with subsequent purification by nanofiltration were substantiated. The high efficiency of the proposed method for extraction of heavy metal ions from aqueous solutions to residual concentrations below the norm using HEDP and NTMP is confirmed. To increase the efficiency of the process, it is advisable to pre-purify water from hardness ions, bicarbonates, chlorides, sulfates on the anion exchange resin in the basic form. For complete extraction of the copper ions it is advisable to use HEDP and NTMP, for zinc and cadmium HEDP is more efficient, while for nickel NTMP is the best option.

4. During the development of this area of research it is planned to formulate methods for further concentration of heavy metal ions in concentrates obtained by nanofiltration. In this case, their complete processing will be ensured with the extraction of heavy metal ions in the form of reduced metals by ion exchange and electroextraction.

\section{References.}

1. Hryniuk, V. I., \& Arkhypova, L. M. (2018). Regularity of effects of climatic changes on quality indicators of surface water of the dniester basin. Naukovyi Visnyk Natsionalnoho Hirnychoho Universytetu, (3), 125-133. https://doi.org/10.29202/ nvngu/2018-3/17.

2. Malik, L.A., Bashir, A., Qureashi, A., \& Pandith, A.H. (2019). Detection and removal of heavy metal ions: A review. Environmental Chemistry Letters, 17(4), 1495-1521.

3. Gorova, A., Pavlychenko, A., Borysovs'ka, O., \& Krups'ka, L. (2013). The development of methodology for assessment of environmental risk degree in mining regions. Annual Scientific-Technical Colletion - Mining of Mineral Deposit, 207209.

4. Korchemlyuk, M., Arkhipova, L., Kravchynskyi, R. L., \& Mykhailyuk, J. D. (2019). Anthropogenic influence from point and diffuse sources of pollution in the upper Prut river basin. Naukovyi Visnyk Natsionalnoho Hirnychoho Universytetu, (1), 125-131. https://doi.org/10.29202/nvngu/2019-1/12.

5. Fashola, M.O., Ngole-Jeme, V.M., \& Babalola, O.O. (2016). Heavy metal pollution from gold mines: Environmental effects and bacterial strategies for resistance. International
Journal of Environmental Research and Public Health, 13(11), art. no. 1047. https://doi.org/10.3390/ijerph13111047.

6. Dixit, R., Wasiullah, Malaviya, D., Pandiyan, K., Singh, U. B., Sahu, A., Shukla, R., ..., \& Paul, D. (2015). Bioremediation of heavy metals from soil and aquatic environment: An overview of principles and criteria of fundamental processes. Sustainability (Switzerland), 7(2), 2189-2212. https://doi.org/10.3390/su7022189.

7. Halysh, V., Sevastyanova, O., Riazanova, A.V., Pasalskiy, B., Budnyak, T., Lindström, M. E., \& Kartel, M. (2018). Walnut shells as a potential low-cost lignocellulosic sorbent for dyes and metal ions, Cellulose, 25(8), 4729-4742. https:// doi.org/10.1007/s10570-018-1896-y.

8. Benavente, D., Pla, C., Valdes-Abellan, J., \& CremadesAlted, S. (2020). Remediation by waste marble powder and lime of jarosite-rich sediments from Portman Bay (Spain). Environmental Pollution, 264, art. no.114786.

9. Vardhan, K. H., Kumar, P. S., \& Panda, R. C. (2019). A review on heavy metal pollution, toxicity and remedial measures: Current trends and future perspectives. Journal of Molecular Liquids, 290, art. no. 111197. https://doi.org/10.1016/j. molliq.2019.111197.

10. Ambiado, K., Bustos, C., Schwarz, A., \& Bórquez, R. (2017). Membrane technology applied to acid mine drainage from copper mining. Water Science and Technology, 75(3), 705-715.

11. Gomelya, M. D., Trus, I. M., \& Radovenchyk, I. V. (2014). Influence of stabilizing water treatment on weak acid cation exchange resin in acidic form on quality of mine water nanofiltration desalination. Naukovyi Visnyk Natsionalnoho Hirnychoho Universytetu, (5), 100-105.

12. Chen, X., Ren, P., Li, T., Trembly, J. P., \& Liu, X. (2018). Zinc removal from model wastewater by electrocoagulation: Processing, kinetics and mechanism. Chemical Engineering Journal, 349, 358-367.

13. Oden, M. K., \& Sari-Erkan, H. (2018). Treatment of metal plating wastewater using iron electrode by electrocoagulation process: Optimization and process performance. Process Safety and Environmental Protection, 119, 207-217. https://doi. org/10.1016/j.psep.2018.08.001.

14. Koliehova, A., Trokhymenko, G., Magas, N., Gomelya, N., \& Trus, I. (2020). Study of the Process of Electro Evolution of Copper Ions from Waste Regeneration Solutions. Journal of Ecological Engineering, 21(2), 29-38.

15. Kvartenko, O., Sabliy, L., Kovalchuk, N., \& Lysytsya, A. (2018). The use of the biological method for treating iron containing underground waters. Journal of Water and Land Development, 39(1), 77-82. https://doi.org/10.2478/jwld-20180061.

16. Hu, K., Xu, D., \& Chen, Y. (2020). An assessment of sulfate reducing bacteria on treating sulfate-rich metal-laden wastewater from electroplating plant. mailto:chenyc@scut. edu.cnJournal of Hazardous Materials, 393, art. no.122376.

17. Kyrii, S. O., Kosogina, I. V., Astrelin, I. M., \& Obodenko, L.S. (2018). Investigation of the properties of activated carbon modified by wastes of alumina production. VoprosyKhimii i Khimicheskoi Tekhnologii, 2, 70-78.

18. Trus, I., Gomelya, N., Trokhymenko, G., Magas, N., \& Hlushko, O. (2019). Determining the influence of the medium reaction and the technique of magnetite modification on the effectiveness of heavy metals sorption. Eastern-European Journal of Enterprise Technologies, 6/10 (102), 49-54.

19. Peng, W., Han, G., Cao, Y., Sun, K., \& Song, S. (2018). Efficiently removing $\mathrm{Pb}(\mathrm{II})$ from wastewater by graphene oxide using foam flotation. Colloids and Surfaces A: Physicochemical and Engineering Aspects, 556, 266-272. https://doi. org/10.1016/i.colsurfa.2018.08.043.

20. Trus, I. M., Fleisher, H.Y., Tokarchuk, V.V., Gomelya, M. D., \& Vorobyova, V. I. (2017). Utilization of the residues obtained during the process of purification of mineral mine water as a component of binding materials. Voprosy Khimii i Khimicheskoi Tekhnologii, (6), 104-109. 


\section{Вивчення особливостей очищення води від іонів важких металів при використанні методу нанофільтрації}

\author{
I. М. Трус ${ }^{1}$, М. Д. Гомеля ${ }^{1}$, I. М. Макаренко ${ }^{1}$, \\ А. С. Хоменко ${ }^{1}$, Г.Г.Трохименко ${ }^{2}$
}

1 - Національний технічний університет України «Київський політехнічний інститут імені Ігоря Сікорського», м. Київ, Україна, e-mail: inna.trus.m@gmail.com

2 - Національний університет кораблебудування імені адмірала Макарова, м. Миколаїв, Україна

Мета. Розробка високоефективних технологій глибокого очищення природних і стічних вод від сполук та іонів важких металів із використанням нанофільтраційних мембран і комплексонів для запобігання забрудненню водойм та захисту людей і природних об'єктів від впливу високотоксичних полютантів.

Методика. Для видалення іонів міді із досліджуваних розчинів у роботі застосовували фероціанід калію як осаджувач, катіонний флокулянт Zetag-7547 для покращення седиментаційних властивостей отриманої твердої фази. Для вилучення іонів міді, цинку, кадмію, нікелю використовували комплексони ОЕДФК і НТМФК у концентрації 10-50 мг/дм ${ }^{3}$. Після додавання реагентів розчини знесолювали на нанофільтраційній мембрані низького тиску ОПМН-П.

Результати. Визначені оптимальні умови очистки води від іонів міді методом комплексоутворення-нанофільтрації. Розроблено спосіб ефективного вилучення 3 води важких металів до допустимих меж при використанні комплексонів $з$ подальшим нанофільтраційним знесоленням.

Наукова новизна. У результаті проведених досліджень встановлена залежність продуктивності нанофільтраційної мембрани ОПМН-П від тиску й селективності по іонах міді, цинку, кадмію, нікелю від ступеню відбору перміату. Встановлена залежність ефективності вилучення даних полютантів від типу й витрати комплексонів. Показано, що іони жорсткості, гідрокарбонати, хлориди, сульфати зменшують селективність нанофільтраційної мембрани по іонах важких металів, тому запропоновано для підвищення ефективності процесу провести попереднє очищення води на аніоніті AB-17-8 в основній формі. Для видалення іонів міді 3 досліджуваних розчинів був застосований в якості осаджувача фероціанід калію, для покращення седиментаційних властивостей отриманої твердої фази був використаний розчин катіонного флокулянту Zetag-7547 iз подальшим доочищенням на нанофільтраційній мембрані, що дозволило підвищити ступінь вилучення іонів $\mathrm{Cu}^{2+}$ до $99,6 \%$.

Практична значимість. У роботі обгрунтовані оптимальні технологічні параметри вилучення іонів важких металів із водних розчинів за допомогою методів нанофільтрації при використанні комплексонів. Розроблені методи вилучення іонів важких металів із водних розчинів дозволяють знизити їх концентрації до нормативних значень. Комплексні технології очищення води від важких металів дають можливість зменшити техногенне навантаження на довкілля за рахунок підвищення якості води та зменшення кількості утворених відходів та покращити екологічну ситуацію в регіоні.

Ключові слова: стічні води, полютанти, важкі метали, іони жорсткості, нанофільтрація, комплексон, селективність

\section{Изучение особенностей очистки воды от ионов тяжелых металлов методом нанофильтрации}

\author{
И. Н. Трус ${ }^{1}$, Н. Д. Гомеля ${ }^{1}$, И. Н. Макаренко ${ }^{1}$, \\ А.С. Хоменко ${ }^{1}$, А. Г. Трохименко ${ }^{2}$
}

1 - Национальный технический университет Украины «Киевский политехнический институт имени Игоря Сикорского», г. Киев, Украина, e-mail: inna.trus.m@gmail.com 2 - Национальный университет кораблестроения имени адмирала Макарова, г. Николаев, Украина

Цель. Разработка высокоэффективных технологий глубокой очистки природных и сточных вод от соединений и ионов тяжелых металлов с использованием нанофильтрационных мембран и комплексонов для предотвращения загрязнения водоемов и защиты людей и природных объектов от воздействия высокотоксичных загрязнителей

Методика. Для удаления ионов меди из исследуемых растворов в работе применяли фероцианид калия как осадитель, катионный флокулянт Zetag-7547 для улучшения седиментационных свойств полученной твердой фазы. Для извлечения ионов меди, цинка, кадмия, никеля использовали комплексоны ОЭДФК и НТМФК в концентрации 10-50 мг/дм³. После добавления реагентов растворы фильтровали на нанофильтрационной мембране низкого давления ОПМН-П.

Результаты. Определены оптимальные условия очистки воды от ионов меди методом комплексообразования-нанофильтрации. Разработан способ эффективного извлечения из воды тяжелых металлов до допустимых пределов при использовании комплексонов с последующим нанофильтрационным обессоливанием.

Научная новизна. В результате проведенных исследований установлена зависимость производительности нанофильтрационной мембраны ОПМН-П от давления и селективности по ионам меди, цинка, кадмия, никеля от степени отбора пермиата. Установлена зависимость эффективности извлечения данных поллютантов от типа и расхода комплексонов. Показано, что ионы жесткости, гидрокарбонаты, хлориды, сульфаты уменьшают селективность нанофильтрационных мембран по ионам тяжелых металлов, поэтому предложено для повышения эффективности процесса провести предварительную очистку воды на анионите AB-17-8 в основной форме. Для удаления ионов меди из исследуемых растворов были применены в качестве осадителя ферроцианид калия, для улучшения седиментационных свойств полученной твердой фазы был использован раствор катионного флокулянта Zetag-7547 с последующей доочисткой на нанофильтрационной мембране, что позволило повысить степень извлечения ионов $\mathrm{Cu}^{2+}$ до 99,6\%.

Практическая значимость. В работе обоснованы оптимальные технологические параметры извлечения ионов тяжелых металлов из водных растворов с помощью методов нанофильтрации при использовании комплексонов. Разработанные методы извлечения ионов тяжелых металлов из водных растворов позволяют снизить их концентрации до нормативных значений. Комплексные технологии очистки воды от тяжелых металлов дают возможность уменьшить техногенную нагрузку на окружающую среду за счет повышения качества воды и уменьшения количества образованных отходов и улучшить экологическую ситуацию в регионе.

Ключевые слова: сточные воды, поллютанты, тяжелые металлы, ионы жесткости, нанофильтрация, комплексоны, селективность

Recommended for publication by T.O. Shablii, Doctor of Technical Sciences. The manuscript was submitted 02.12.19. 